\title{
Low dietary calcium in European postmenopausal osteoporotic women
}

\author{
Olivier Bruyere* ${ }^{\star}$, Caroline De Cock, Catherine Mottet, Audrey Neuprez, \\ Olivier Malaise and Jean-Yves Reginster \\ WHO Collaborating Center for Public Health Aspects of Osteoarticular Disorders and Department of Public \\ Health, Epidemiology and Health Economics, University of Liege, Liege, Belgium
}

Submitted 11 September 2007: Accepted 13 February 2008: First published online 15 April 2008

\begin{abstract}
Objective: The WHO recommends a daily Ca intake for postmenopausal women of $1300 \mathrm{mg}$. The objective of the present study was to assess the dietary Ca intake in European postmenopausal osteoporotic women.

Design, setting and subjects: Assessment of dietary Ca intake (food and supplements) was performed with a validated self-questionnaire in 8524 osteoporotic women from nine European countries (Belgium, Denmark, France, Germany, Hungary, Italy, Poland, Spain and the UK).

Results: Mean age of the patients was $74 \cdot 2$ (SD $7 \cdot 1$ ) years, mean BMI was $25 \cdot 7$ (SD $4 \cdot 2) \mathrm{kg} / \mathrm{m}^{2}$. Of the study population, $37 \cdot 2 \%$ of the women took Ca supplements. The mean dietary intake of Ca was $930 \cdot 7$ (sD 422.9) $\mathrm{mg} / \mathrm{d}$. The lowest Ca intake was found in Hungary (586.7 (sD 319.1) $\mathrm{mg} / \mathrm{d}$ ) and the highest in Denmark $(1145.6(\mathrm{sD} 463 \cdot 0) \mathrm{mg} / \mathrm{d})$. In the whole study population, only $19 \cdot 1 \%$ of the women had a dietary Ca intake $>1300 \mathrm{mg} / \mathrm{d}$. Only $17 \cdot 1 \%$ of women aged over 75 years achieved $1300 \mathrm{mg} / \mathrm{d}$ compared with $20.5 \%$ of women aged less than 75 years $(P=0 \cdot 0001$ for the difference between the two groups). Conclusion: Dietary intake of $\mathrm{Ca}$ is very low in European postmenopausal women. A greater awareness is needed to resolve this public health problem.
\end{abstract}

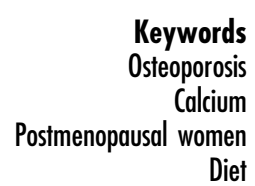

Keywords Calcium

Diet
Osteoporosis is characterized by increased skeletal fragility and susceptibility to fractures, leading to a significant increase in morbidity and mortality ${ }^{(1)}$. Because of the ageing of the European population, a preventive strategy for osteoporosis has become a public health priority.

$\mathrm{Ca}$ is an essential nutrient that plays a vital role in neuromuscular function, many enzyme-mediated processes, blood clotting, and provides rigidity to the skeleton by virtue of its phosphate salts ${ }^{(2)}$. Ca consumption also influences the maintenance of bone mass ${ }^{(3)}$. Nearly all (i.e. 99\%) of total body $\mathrm{Ca}$ is located in the skeleton and the remaining $1 \%$ is equally distributed between the teeth and soft tissues, with only $0 \cdot 1 \%$ in the extracellular compartment ${ }^{(2,4)}$.

The Ca needs for adults are generally recognized as the intake required to maintain $\mathrm{Ca}$ balance and, therefore, skeletal integrity ${ }^{(2,5)}$. The Recommended Dietary Allowance (RDA) for European adults is $800 \mathrm{mg} / \mathrm{d}^{(6)}$. After menopause, Ca requirements increase to at least $1000 \mathrm{mg} / \mathrm{d}^{(7,8)}$.

\footnotetext{
$\uparrow$ Correspondence address: Department of Public Health, Epidemiology and Health Economics, University of Liege, CHU Sart-Tilman, B-4000 Liège, Belgium.
}

The WHO recommendation for European postmenopausal women is $1300 \mathrm{mg} / \mathrm{d}^{(2,3)}$.

The objective of the present study was to assess the daily dietary $\mathrm{Ca}$ intake in European postmenopausal osteoporotic women.

\section{Methods}

Postmenopausal women aged over 50 years were included in the study. These women were part of a run-in study aimed at normalizing the $\mathrm{Ca}$ and vitamin D status of osteoporotic patients prior to their inclusion in a trial investigating the anti-fracture efficacy of a new antiosteoporotic drug. Patients were considered osteoporotic if their lumbar spine or femoral neck bone mineral density was at least $2 \cdot 5$ standard deviations below the median T-score.

The present study involved 8524 patients from nine European countries: Belgium ( $n$ 1193), Denmark ( $n$ 327), France ( $n$ 1290), Germany ( $n$ 373), Hungary ( $n$ 353), Italy ( $n$ 1233), Poland ( $n$ 1544), Spain $(n$ 590) and the UK (n 1621). 
Table 1 Baseline characteristics of women according to category of dietary calcium intake: European postmenopausal osteoporotic women

\begin{tabular}{|c|c|c|c|c|c|c|}
\hline \multirow[b]{2}{*}{ Characteristic } & \multicolumn{2}{|c|}{$<800 \mathrm{mg} / \mathrm{d}$} & \multicolumn{2}{|c|}{$800-1300 \mathrm{mg} / \mathrm{d}$} & \multicolumn{2}{|c|}{$>1300 \mathrm{mg} / \mathrm{d}$} \\
\hline & Mean & SD & Mean & SD & Mean & SD \\
\hline$n$ & \multicolumn{2}{|c|}{3536} & \multicolumn{2}{|c|}{3360} & \multicolumn{2}{|c|}{1628} \\
\hline Age (years) & $74 \cdot 8$ & $7 \cdot 3$ & $74 \cdot 1$ & $7 \cdot 0$ & $73 \cdot 3$ & $6 \cdot 7$ \\
\hline BMl $\left(\mathrm{kg} / \mathrm{m}^{2}\right)$ & $26 \cdot 0$ & $4 \cdot 3$ & $25 \cdot 7$ & $4 \cdot 1$ & $25 \cdot 3$ & $4 \cdot 0$ \\
\hline Lumbar spine BMD $\left(\mathrm{g} / \mathrm{cm}^{2}\right)$ & 0.77 & $0 \cdot 13$ & 0.77 & $0 \cdot 13$ & 0.77 & $0 \cdot 13$ \\
\hline Femoral neck BMD $\left(\mathrm{g} / \mathrm{cm}^{2}\right)$ & 0.55 & 0.08 & 0.55 & 0.08 & 0.56 & 0.08 \\
\hline 25-Hydroxycalciferol (nmol//) & $57 \cdot 7$ & $27 \cdot 1$ & $62 \cdot 7$ & $27 \cdot 1$ & $64 \cdot 8$ & $26 \cdot 7$ \\
\hline
\end{tabular}

$\mathrm{BMD}$, bone mineral density.

Assessment of Ca intake was performed with a previously validated self-questionnaire ${ }^{(9)}$. This questionnaire enables evaluation of the Ca content of the diet of an individual on the basis of twenty different types of food (items) rich in $\mathrm{Ca}$ and/or frequently eaten. Obviously, tablets of Ca taken as supplements were also considered. Our study population was divided into three categories of $\mathrm{Ca}$ consumption: $<800 \mathrm{mg} / \mathrm{d}$, 800-1300 mg/d and $>1300 \mathrm{mg} / \mathrm{d}$. These thresholds were fixed according to the RDA for European adults $(800 \mathrm{mg} / \mathrm{d})^{(6)}$ and the WHO recommendation for European postmenopausal women $(1300 \mathrm{mg} / \mathrm{d})^{(2)}$.

\section{Results}

The mean age of the 8524 women included in the present study was $74 \cdot 2(\mathrm{SD} 7 \cdot 1)$ years, mean BMI was $25 \cdot 7(\mathrm{SD} 4 \cdot 2)$ $\mathrm{kg} / \mathrm{m}^{2}$. Table 1 shows the characteristics of the patients according to category of dietary Ca intake (i.e. $<800 \mathrm{mg} / \mathrm{d}$, $800-1300 \mathrm{mg} / \mathrm{d},>1300 \mathrm{mg} / \mathrm{d}$ ).

In the whole study population, $37 \cdot 2 \%$ of the women took Ca supplements $(34.9 \%$ of women aged over 75 years and $38.9 \%$ of women aged less than 75 years). Mean daily food intake was significantly lower $(P<0.001)$ in subjects who did not take a Ca supplement.

The mean dietary $\mathrm{Ca}$ intake (food plus supplements) was 930.7 (sD 422.9$) \mathrm{mg} / \mathrm{d}$. Only $19 \cdot 1 \%$ of women ( $n$ 1628) had daily dietary Ca consumption $>1300 \mathrm{mg}$. Moreover, 39.4\% ( $n$ 3360) of the study population had daily $\mathrm{Ca}$ dietary intake of $800-1300 \mathrm{mg}$ and $41.5 \%$ ( $n$ 3536) had an intake of $<800 \mathrm{mg}$ daily (Fig. 1).

Daily $\mathrm{Ca}$ intake from food and supplements, stratified by country, is shown in Table 2 . The highest level of daily Ca intake from food was found in Denmark $(1145.6 \mathrm{mg} / \mathrm{d})$ and the smallest in Hungary $(586.7 \mathrm{mg} / \mathrm{d})$. Figure 2 shows the proportions of women in the different countries according to intake category (i.e. $<800 \mathrm{mg} / \mathrm{d}, 800-1300 \mathrm{mg} / \mathrm{d}$, $>1300 \mathrm{mg} / \mathrm{d}$ ).

We found the lowest dietary Ca inadequacy in women aged over 75 years compared with women aged less than 75 years $(P<0 \cdot 0001)$. Only $17 \cdot 1 \%$ of women aged over 75 years achieved $1300 \mathrm{mg} / \mathrm{d}$ compared with $20.5 \%$ of women aged less than 75 years $(P=0 \cdot 0001$ for the difference between the two groups) (Fig. 1).

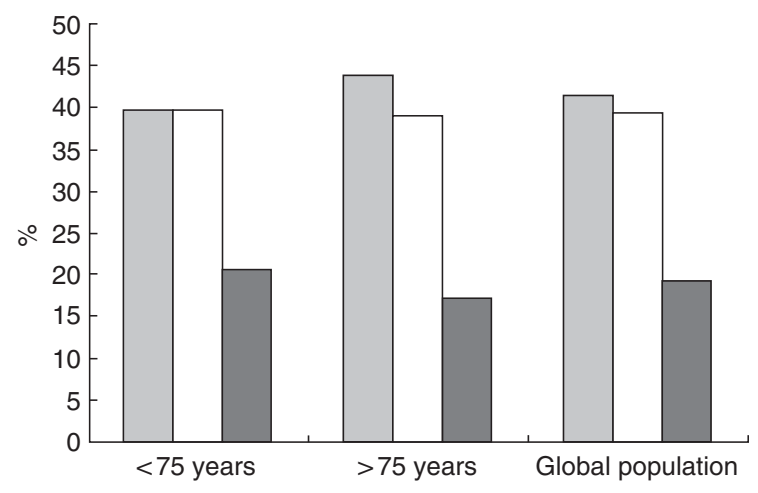

Fig. 1 Proportion of women in the global population, women aged less than 75 years and women more than 75 years of age meeting different thresholds ( $\square,<800 \mathrm{mg} / \mathrm{d}$; $\square, 800-1300 \mathrm{mg} / \mathrm{d}$; $\square,>1300 \mathrm{mg} / \mathrm{d}$ ) of dietary calcium intake: European postmenopausal osteoporotic women

Table 2 Dietary calcium intake and the percentage of women taking calcium supplements in different countries: European postmenopausal osteoporotic women

\begin{tabular}{|c|c|c|c|c|}
\hline & \multirow[b]{2}{*}{$n$} & \multicolumn{2}{|c|}{ Dietary Ca intake $(\mathrm{mg} / \mathrm{d})$} & \multirow[b]{2}{*}{ Supplements (\%) } \\
\hline & & Mean & SD & \\
\hline Belgium & 1193 & $791 \cdot 8$ & $394 \cdot 7$ & $45 \cdot 5$ \\
\hline Denmark & 327 & $1145 \cdot 6$ & $463 \cdot 0$ & $33 \cdot 6$ \\
\hline France & 1290 & $1019 \cdot 4$ & $392 \cdot 2$ & $46 \cdot 5$ \\
\hline Germany & 373 & $1060 \cdot 7$ & $470 \cdot 1$ & $53 \cdot 9$ \\
\hline Hungary & 353 & $586 \cdot 7$ & $319 \cdot 0$ & $16 \cdot 7$ \\
\hline Italy & 1233 & $945 \cdot 1$ & $380 \cdot 0$ & $41 \cdot 9$ \\
\hline Poland & 1544 & $693 \cdot 9$ & $367 \cdot 0$ & $20 \cdot 1$ \\
\hline Spain & 590 & $1074 \cdot 3$ & $374 \cdot 2$ & $64 \cdot 2$ \\
\hline UK & 1621 & $1126 \cdot 6$ & $373 \cdot 9$ & $28 \cdot 4$ \\
\hline
\end{tabular}

\section{Discussion}

We have shown that the mean dietary Ca intake of European postmenopausal osteoporotic women was below the WHO recommendation. The majority of these women (41.5\%) took less $\mathrm{Ca}$ than that recommended for adults before menopause $(800 \mathrm{mg} / \mathrm{d})$ and only $19 \cdot 1 \%$ of them achieved the WHO recommendation $(1300 \mathrm{mg} / \mathrm{d})$ for this population. The level of daily Ca intake from food varied across different European countries but always remained below the WHO-recommended intake. 


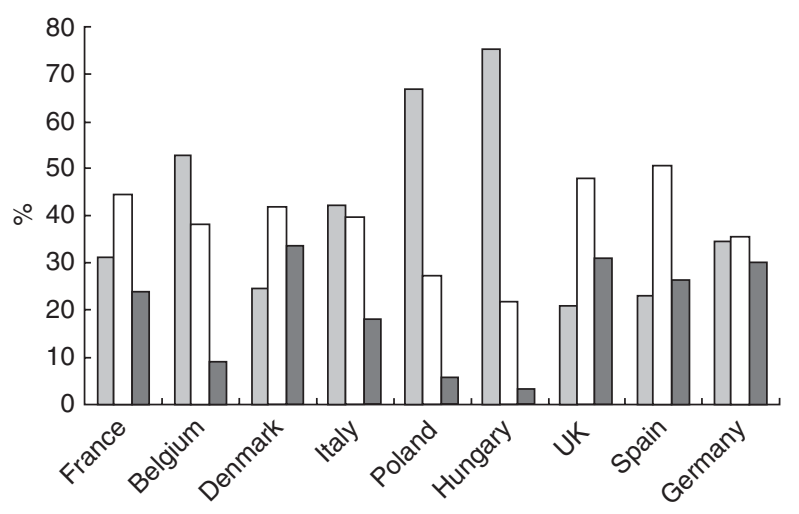

Fig. 2 Proportion of women in different European countries meeting different thresholds ( $\square,<800 \mathrm{mg} / \mathrm{d}$; $\square, 800-1300 \mathrm{mg} / \mathrm{d}$; $\square,>1300 \mathrm{mg} / \mathrm{d}$ ) of dietary calcium intake: European postmenopausal osteoporotic women

Other epidemiological studies have described low dietary Ca intake. In 131 healthy postmenopausal women aged $64 \cdot 7$ (SD 7.6) years, Andon et al. found mean Ca consumption of $606(\mathrm{sD} 302) \mathrm{mg} / \mathrm{d}^{(10)}$. In late ( $\geq 5$ years) postmenopausal women, Jensen et al. ${ }^{(11)}$ described mean Ca consumption of 793 (sD 280) $\mathrm{mg} / \mathrm{d}$ in women aged 65 years and older. In 184 elderly women aged over 65 years, Pfister et $a l .{ }^{(12)}$ found a mean dietary Ca intake of $563.4 \mathrm{mg} / \mathrm{d}$. The combined dietary $\mathrm{Ca}$ intake and supplement Ca intake in elderly women ( $>60$ years old) participating in NHANES III (Third National Health and Nutrition Examination Survey) was 864 (SD 16) mg/d ${ }^{(13)}$. In a recent study, the mean dietary Ca intake reported by 167 postmenopausal women aged 40-65 years was 924 (sD 347$) \mathrm{mg} / \mathrm{d}^{(14)}$.

Subjects included in the present study were women being screened for taking part in a study assessing the antifracture efficacy of a new anti-osteoporotic drug in postmenopausal osteoporosis. Other studies performed in such populations (i.e. screening for randomized controlled trials of anti-osteoporotic drugs) also described low Ca intake in postmenopausal osteoporotic women ${ }^{(15-20)}$. For example, in 1637 postmenopausal women with prior vertebral fractures, mean daily intake of $\mathrm{Ca}$ from food ranged from $675 \mathrm{mg}$ to $786 \mathrm{mg}$ in the different randomized groups ${ }^{(19)}$. In the baseline characterization of the Fracture Intervention Trial ${ }^{(16)}$, the mean Ca intake was $619 \mathrm{mg} / \mathrm{d}$ for the placebo group ( $n$ 1005) and $652 \mathrm{mg} / \mathrm{d}$ for the treatment group ( $n$ 1022).

In the present study, we have shown that the daily intake of Ca from food was low and that only $37 \cdot 2 \%$ of the women took Ca supplements. Foods provide the best way to meet the Ca requirement because they constitute good sources of other essential nutrients ${ }^{(3)}$. However, dietary $\mathrm{Ca}$ intake has been found to be dependent on socio-economic status ${ }^{(21)}$ and personal attitudes towards food (i.e. milk) ${ }^{(12)}$. Moreover, it is difficult to achieve vitamin and mineral requirements when daily energy intake is below $6 \cdot 28 \mathrm{MJ}(1500 \mathrm{kcal})^{(22-24)}$. Thus different expert groups have recommended use of Ca supplements by postmenopausal osteoporotic women ${ }^{(25-27)}$. In the present study, it appeared that women who took $\mathrm{Ca}$ supplements had higher mean daily $\mathrm{Ca}$ intake from food $(P<0.001)$ compared with women who did not take supplements, probably because of a greater awareness of their osteoporosis disease.

Osteoporotic fractures occur predominantly in populations aged over 65 years ${ }^{(28)}$. Elderly populations have lower daily intakes of vitamins and minerals compared with younger populations ${ }^{(29)}$, partly because of a lower food intake. In the present study, we found the highest dietary $\mathrm{Ca}$ inadequacy in women aged less than 75 years compared with women aged over 75 years. Only $17 \cdot 1 \%$ of women aged over 75 years achieved $1300 \mathrm{mg} \mathrm{Ca} / \mathrm{d}$ compared with $20.5 \%$ of women aged less than 75 years. We used the WHO recommendation for postmenopausal women to set up a threshold of $1300 \mathrm{mg} / \mathrm{d}$, but the National Institutes of Health consensus group recommends a Ca consumption of at least $1500 \mathrm{mg} / \mathrm{d}$ after 65 years ${ }^{(8,30)}$. Our results confirm the difficulty in achieving correct daily Ca intake by food consumption alone in old postmenopausal women. Unfortunately, it should be pointed out that only $36 \cdot 8 \%$ of these women used Ca supplements.

In the present study we assessed dietary $\mathrm{Ca}$ intake of a population screened prior to inclusion in a trial investigating the anti-fracture efficacy of an anti-osteoporotic drug. Because of the patient inclusion/exclusion criteria in this particular study, our population cannot be representative of the general population but more of an osteoporotic population starting a treatment.

Another limitation of the study relates to the Ca intake assessment, which was performed with a validated selfquestionnaire $^{(9)}$. However, it should be pointed that some studies have found that some dietary recalls and records could have an underestimation of $25-30 \%$. However, even if our data are underestimated, our conclusion that dietary $\mathrm{Ca}$ intake is very low in European postmenopausal women is still true and could even be more serious.

Osteoporosis and its consequences are a serious public health problem in the ageing population ${ }^{(1,31)}$. Our study shows insufficient dietary $\mathrm{Ca}$ intakes in postmenopausal osteoporotic women (whatever the age) in nine European countries. A substantial part of our study population does not achieve the general recommendation for $\mathrm{Ca}$ intake in such a population. We believe that greater awareness of this public health problem could help the fight against osteoporosis.

\section{Acknowledgements}

Declaration of interest: The authors declare that they have no competing interest. No industry funding was 
received for the study. The authors thank Servier for providing access to their database.

Author contributions: design of the study - O.B. and J.-Y.R.; analysis of the results - O.B., C.D.C., C.M., A.N. and O.M.; interpretation of the results - O.B., C.D.C., C.M. and J.-Y.R.; draft of the manuscript - O.B. and C.D.C.; final approval of the manuscript - all authors.

\section{References}

1. Gallagher JC, Fowler SE, Detter JR \& Sherman SS (2001) Combination treatment with estrogen and calcitriol in the prevention of age-related bone loss. J Clin Endocrinol Metab 86, 3618-3628.

2. Food and Agriculture Organization of the United Nations/ World Health Organization (2002) Human vitamin and mineral requirements. http://www.fao.org/docrep/004/ Y2809E/y2809e0h.htm\#bm17.6 (accessed October 2006).

3. Heaney RP (2001) Calcium needs of the elderly to reduce fracture risk. J Am Coll Nutr 20, Suppl., 192S-197S.

4. Robertson WG \& Marshall RW (1981) Ionized calcium in body fluids. Crit Rev Clin Lab Sci 15, 85-125.

5. Ilich JZ, Brownbill RA \& Tamborini L (2003) Bone and nutrition in elderly women: protein, energy, and calcium as main determinants of bone mineral density. Eur J Clin Nutr $\mathbf{5 7 , 5 5 4 - 5 6 5 . ~}$

6. Hautvast JG, Baya C, Amorim Cruz JA et al. (1989) Recommended dietary allowances for Europe. Lancet 2, 1220 .

7. Heaney RP, Recker RR \& Saville PD (1978) Menopausal changes in calcium balance performance. J Lab Clin Med 92, 953-963.

8. NIH Consensus conference (1994) Optimal calcium intake. NIH Consensus Development Panel on Optimal Calcium Intake. JAMA 272, 1942-1948.

9. Fardellone P, Sebert JL, Bouraya M, Bonidan O, Leclercq G, Doutrellot C, Bellony R \& Dubreuil A (1991) [Evaluation of the calcium content of diet by frequential self-questionnaire]. Rev Rhum Mal Osteoartic 58, 99-103.

10. Andon MB, Smith KT, Bracker M, Sartoris D, Saltman P \& Strause L (1991) Spinal bone density and calcium intake in healthy postmenopausal women. Am J Clin Nutr 54, 927-929.

11. Jensen C, Holloway L, Block G, Spiller G, Gildengorin G, Gunderson E, Butterfield G \& Marcus R (2002) Long-term effects of nutrient intervention on markers of bone remodeling and calciotropic hormones in late-postmenopausal women. Am J Clin Nutr 75, 1114-1120.

12. Pfister AK, Wul JT Jr \& Saville PD (2001) Factors determining calcium intake in elderly women of Appalachia. South Med J 94, 1006-1012.

13. Ervin RB \& Kennedy-Stephenson J (2002) Mineral intakes of elderly adult supplement and non-supplement users in the third National Health and Nutrition Examination Survey. J Nutr 132, 3422-3427.

14. Cussler EC, Going SB, Houtkooper LB, Stanford VA, Blew RM, Flint-Wagner HG, Metcalfe LL, Choi JE \& Lohman TG (2005) Exercise frequency and calcium intake predict 4 -year bone changes in postmenopausal women. Osteoporos Int 16, 2129-2141.

15. Liberman UA, Weiss SR, Broll J, Minne HW, Quan H, Bell NH, Rodriguez-Portales J, Downs RW Jr, Dequeker J \&
Favus M (1995) Effect of oral alendronate on bone mineral density and the incidence of fractures in postmenopausal osteoporosis. The Alendronate Phase III Osteoporosis Treatment Study Group. N Engl J Med 333, 1437-1443.

16. Black DM, Cummings SR, Karpf DB et al. (1996) Randomised trial of effect of alendronate on risk of fracture in women with existing vertebral fractures. Fracture Intervention Trial Research Group. Lancet $\mathbf{3 4 8}$, $1535-1541$.

17. Cummings SR, Black DM, Thompson DE et al. (1998) Effect of alendronate on risk of fracture in women with low bone density but without vertebral fractures: results from the Fracture Intervention Trial. JAMA 280, 2077-2082.

18. Chesnut CH 3rd, Silverman S, Andriano K et al. (2002) A randomized trial of nasal spray salmon calcitonin in postmenopausal women with established osteoporosis: the prevent recurrence of osteoporotic fractures study. PROOF Study Group. Am J Med 109, 267-276.

19. Neer RM, Arnaud CD, Zanchetta JR et al. (2001) Effect of parathyroid hormone (1-34) on fractures and bone mineral density in postmenopausal women with osteoporosis. $N$ Engl J Med 344, 1434-1441.

20. Reid IR, Ames RW, Evans MC, Gamble GD \& Sharpe SJ (1993) Effect of calcium supplementation on bone loss in postmenopausal women. $N$ Engl J Med 328, 460-464.

21. Winzenberg TM, Riley M, Frendin S, Oldenburg B \& Jones G (2005) Sociodemographic factors associated with calcium intake in premenopausal women: a cross-sectional study. Eur J Clin Nutr 59, 463-466.

22. Schlienger JL, Pradignac A \& Grunenberger F (1995) Nutrition of the elderly: a challenge between facts and needs. Horm Res 43, 46-51.

23. Meunier F (2005) [Nutrition in the elderly person]. Soins Gerontol issue 51, 16-18.

24. Walker J \& Ball M (1993) Increasing calcium intake in women on a low-fat diet. Eur J Clin Nutr 47, 718-723.

25. Boonen S, Rizzoli R, Meunier PJ, Stone M, Nuki G, Syversen U, Lehtonen-Veromaa M, Lips P, Johnell O \& Reginster JY (2004) The need for clinical guidance in the use of calcium and vitamin $\mathrm{D}$ in the management of osteoporosis: a consensus report. Osteoporos Int 15, 511-519.

26. Boonen S, Body JJ, Boutsen Y, Devogelaer JP, Goemaere S, Kaufman JM, Rozenberg S \& Reginster JY (2005) Evidencebased guidelines for the treatment of postmenopausal osteoporosis: a consensus document of the Belgian Bone Club. Osteoporos Int 16, 239-254.

27. Compston J (2005) Guidelines for the management of osteoporosis: the present and the future. Osteoporos Int 16, 1173-1176.

28. Dhesi JK, Allain TJ, Mangoni AA \& Jackson SH (2006) The implications of a growing evidence base for drug use in elderly patients. Part 4. Vitamin D and bisphosphonates for fractures and osteoporosis. Br J Clin Pharmacol 61, 521-528.

29. Mowe M \& Bohmer T (2002) Reduced appetite. A predictor for undernutrition in aged people. J Nutr Health Aging $\mathbf{6}$, $81-83$.

30. Lowenstein FW (1982) Nutritional status of the elderly in the United States of America, 1971-1974. J Am Coll Nutr 1, 165-177.

31. Boonen S, Bischoff-Ferrari HA, Cooper C, Lips P, Ljunggren O, Meunier PJ \& Reginster JY (2006) Addressing the musculoskeletal components of fracture risk with calcium and vitamin D: a review of the evidence. Calcif Tissue Int $\mathbf{7 8}$, 257-270. 